\title{
The Impact of a Hexaconazole Fungicide on Agronomic, Biochemical Parameters and Yield Components of Green Beans PhaseolusVulgaris cv. Djedida
}

\author{
Bourouhou Mourad, Boudouna Baha-Eddine and Boudelaa Mokhtar
}

\begin{abstract}
The use of synthetic phytosanitary products has proved to be very effective in controlling crop diseases and pests in a significant number of cases, however, many studies and studies concern the presence of these molecules in the soil, contamination of the waters we have to say confirmed the degradation of living ecosystems.

The aim of this work is to verify the effect of the fungicide Hexaconazole on agronomic, biochemical markers and enzymatic activity of a legume green bean Phaseolus vulgaris, cv. Djedida. Four treatment doses were chosen with control namely Dosel $(0.4 \mathrm{ml} / \mathrm{l})$, Dose2 $(0.8 \mathrm{ml} / \mathrm{l})$, dose $3(1.2 \mathrm{ml} / \mathrm{l})$, Dose4 $(1.6 \mathrm{ml} / \mathrm{l})$. The obtained results show that all variables studied agronomic, physiologic and enzymatic are relatively stable for plants treated with low doses $0.4 \mathrm{ml} / \mathrm{l}$ and $0.8 \mathrm{ml} / \mathrm{l}$. against, the plants treated by highest doses D3 and D4 recorded the lowest values. The dose effect is decisive and proportional to the applied level. The analysis of the mechanisms of response to oxidative stress or oxidative stressxenobiotic interactions may therefore provide a better understanding of the processes of response to xenobiotic.
\end{abstract}

Keywords

\section{INTRODUCTION}

Algeria is among the countries that use large amounts of pesticides. Thus, about 400 pesticidesare registered including forty varieties are widely used by farmers [1].

Given this situation, all stakeholders (production units, producers, technical staff and researchers) must anticipate future changes and increase their responsiveness by continually seeking information as a basic tool for effective phytosanitary protection and respect for the environment. [2] [3] [4], but the environmental consequences have continued to increase. Many works and studies related to the presence of these molecules in the soil [5], water contamination, On the other hand, the degradation of living ecosystems [6] [7], their use as a source of carbon by microorganisms present in the soil and finally the identification of residues that apparently seem to be related to pesticides [8]. Advances in crop protection are remarkable, but created environmental imbalances have a close dependence on pesticides [9].

The latter inhibits root development [10], induced chlorosis of leaves [11], reduced photosynthesis [12] and inhibited or activated severely enzymes [13]. The pesticides enter the leaves by the stomata are transported inside the cells and can thus harm the normal respiration is also to the mechanisms of photosynthesis by altering chlorophyll, Electron transport and oxidative phosphorylation. They can also disrupt biochemical activity, including the synthesis of carbohydrates and some amino acids under unfavourable environmental conditions, the plant is weakened and therefore unable to make the most of its environment [14].

The objective of this work is to know the answers agronomic parameters, biochemical and green bean yield components subjected to chemical stress based systemic fungicide: the Hexaconazole.

\section{MATERIALS AND METHODS}

The systemic fungicide is Anvil original (Zeneca), based Hexaconazole, which is the active ingredient belongs to the chemical family of triazoles. The chemical formula is $\mathrm{C}_{14} \mathrm{H}_{17} \mathrm{C}_{12} \mathrm{~N}_{3} \mathrm{O}$. Available in Algeria used for vegetable crops and fruit trees. The experiment was conducted under greenhouse with a completely random device. Seeded with five seeds per pot, on a balanced soil texture, at a depth of $2 \mathrm{cmFour}$ (4) selected doses of the fungicide are dissolved in distilled water with five repetitions. The doses used for this work are the dose $1(0.4 \mathrm{ml} / \mathrm{l})$, the dose $2(0.8$ $\mathrm{ml} / \mathrm{l})$, the dose $3(1.2 \mathrm{ml} / \mathrm{l}), 4$ dose $(1.6 \mathrm{ml} / \mathrm{l})$ and the reference dose, dose field or DC $(0.8 \mathrm{ml} / \mathrm{l})$. Two fungal treatments were applied by spraying, from the $6^{\text {th }}$ week after emergence for the first, and in the $9^{\text {th }}$ week after emergence for the second treatment. After each treatment analyzes of agronomic and physiological parameters are performed. The experiment of planting until harvest lasted four months.

\section{PARAMETERS STUDIED}

A. The agronomic parameters 
The agronomic parameters studied are: the length of the aerial part of the plant (LAP) and leaf area (LA) by the method described by Paul and al [15].

\section{B. Determination of Chlorophyll and Carotenoid Pigments}

The dosage of the chlorophyll and carotenoid pigments is performed by the method of Holden [16]. The idea isto be weighed $(0.2 \mathrm{~g})$ of green leaves, grind the min a mortar with a pinch of calcium carbonate $(\mathrm{CaCO} 3)$ to neutralize vacuolar acidity and $25 \mathrm{ml} 80 \%$ acetone. Chlorophyll isdetermined by the spectrophotometric method, which allows the reading of optical densities(OD) of the extract sat 645 and $663 \mathrm{~nm}$, then solving the equation system of Arnon [17] give us the contents of chlorophylls (a) and (b) and carotenoids in $\mathrm{mg} / \mathrm{g}$ of FM (Fresh matter).

\section{Total Protein Content Preparation of the Sample:}

$(0.1 \mathrm{~g})$ of the sample of each concentration is ground in a mortar with $5 \mathrm{ml}$ of distilled water and then filtered and poured into tubes with distilled water.

Proteins were quantified according to the method of Bradford [18],using Coomassie G250 brilliant blue (BBC) and bovine serum albumin (BSA) as the standard.

\section{Total Sugar Content Preparation of the Sample:}

The sugars are determined by the method Shields and Burnett [19],which uses anthrone in a sulfuric medium, extraction of the soluble sugars is carried out after maceration of $(0.1 \mathrm{~g})$ of vegetable matter in $3 \mathrm{ml}$ of $80 \%$ ethanol for 45 hours. Then pass the tubes to the rotavapor for evaporation of the ethanol, and then put $20 \mathrm{ml}$ of distilled water in the whole of the extract.

\section{E. Measurement of yield Components}

Regarding yield components such as the number of knotted flowers, Number of pods per plant, Weight of 100 Seeds, using a graduated scale and a precision scale.

\section{RESULTS}

\section{A. The Agronomic Parameters}

\section{a. Length Of Theaerial Partof The Plant (LAP)}

Fig (1) shows the growth in length of the plants over time after treatments with the fungicide Hexaconazole. This characteristic varies from highly significant manner $(\mathrm{P}<0.001)$ (Table.1). The results show that the highest average were observed in plants treated with the lowest dose $1(0.4 \mathrm{ml} / \mathrm{l})$ and the control with 36.5 cmon average, by against, doses $\left(\mathrm{D}_{3}\right.$ and $\left.\mathrm{D}_{4}\right)$ have induced the lowestvalueswith35 and34cmin succession for the first treatmentand 36.5 and $34.8 \mathrm{cmfor}$ the second treatment, respectively.

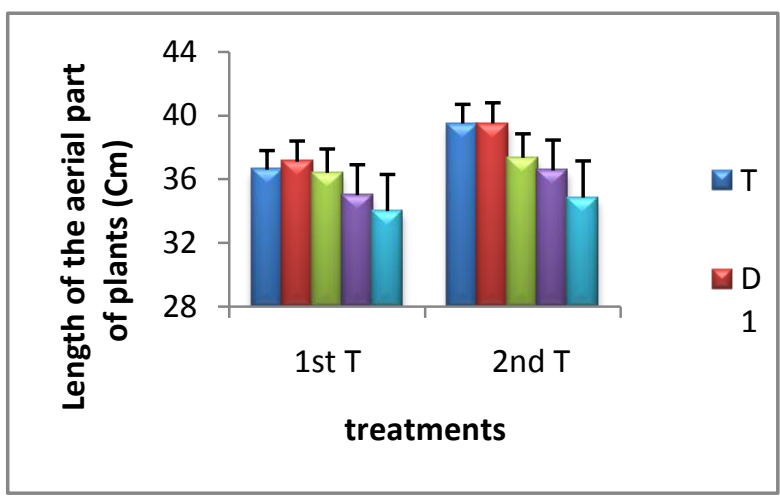

Fig. 1. Effect of Hexaconazoleon length aerial part of plants of green beans treated with different concentrations: $D 1(0.4 m l / l), D_{2}(0.8 m l / l), D_{3}(1.2 m l / l), D_{4}(1.6 m l / l)$, conducted in two processing operations at the $6^{\text {th }}$ and $9^{\text {th }}$ week.

\section{b. Leaf Area}

The observation of the evolution of the leaf area over time after two fungal treatment operations by different doses shows that this character does not vary significantly in the plants for the first treatment although slight differences are noted between Mean values of plants treated with dose D1, The doses D2, D3, D4 with respect to the controls and representing $44.4,46.8,43.8$ and $45.8 \mathrm{~cm} 2$ respectively, then it becomes significant for the second treatment, the D1 records the highest value with a value of $47.8 \mathrm{~cm} 2$ followed by the control With a value of $45.8 \mathrm{~cm} 2$, the plants treated with the highest doses recorded the lowest value of $39.3 \mathrm{~cm} 2$.

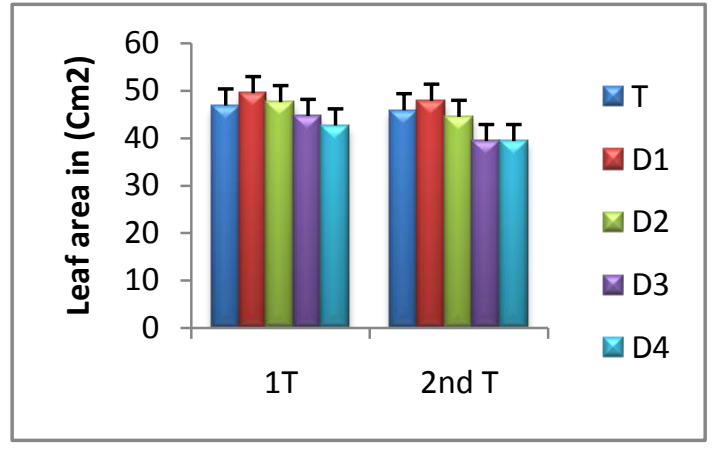

Fig. 2. Effect of Hexa conazoleon leaf area of green beans treated with different concentrations: $D_{l}(0.4 \mathrm{ml} / \mathrm{l})$, $D_{2}(0.8 \mathrm{ml} / \mathrm{l}), D_{3}(1.2 \mathrm{ml} / \mathrm{l}), D_{4}(1.6 \mathrm{ml} / \mathrm{l})$, conducted in two processing operations at the $6^{\text {th }}$ and $9^{\text {th }}$ week.

Table 1. Statistical values of Fobserved (Fobs) analysis of variance ANOVA.1 for agronomic parameters during the first and second treatment.

\begin{tabular}{|c|c|c|c|}
\hline Source of variation & DF & LAP & LA \\
\hline Treatments & & $\mathrm{T}_{1} \mathrm{~T}_{2}$ & $\mathrm{~T}_{1} \mathrm{~T}_{2}$ \\
\hline $\begin{array}{l}\text { Concentration } \\
\text { Error }\end{array}$ & $\begin{array}{c}4 \\
45\end{array}$ & $5,4^{\mathrm{b}} 5,5^{\mathrm{b}}$ & $0,46^{\mathrm{ns}} 2.7^{\mathrm{c}}$ \\
\hline Total & 49 & & \\
\hline
\end{tabular}

Abreaction:

DF: degree of freedom; LAP: length of the aerial part; LA: leaf area; a) $\mathrm{P}<0.05$ : Significant differences; b) $\mathrm{P}$

Bourouhou Mourad, Boudouna Baha-Eddine and Boudelaa Mokhta, "Impact of a Hexaconazole Fungicide on Agronomic, Biochemical Parameters and Yield Components of Green Beans Phaseolus Vulgaris cv. Djedida," International Journal of Advanced Engineering and Management, Vol. 2, No. 6, pp. 146-152, 2017. DOI: https://doi.org/10.24999/IJOAEM/02060035 
<0.01: Highly significant differences; c)P <0.001: Very highly significant differences; $n s=$ Not significant. $\mathrm{T}_{1}$ : First treatment, $\mathrm{T}_{2}$ : second treatment.

\section{B. The biochemical parameters}

\section{a. Pigment Content}

The analysis of variance ANOVA shows that there are very highly significant differences between the averages measured various different doses of treatment. Chlorophyll (a), plants of lot D1, D2 and control, recorded the highest values with 2.45, 2.02 and $2.26 \mu \mathrm{g} / \mathrm{g}$ of FM respectively. For the first treatment, for the 2nd treatment it becomes weaker with $1.63 \mu \mathrm{g} / \mathrm{g}$ for the control and $1.43 \mu \mathrm{g} / \mathrm{g}$ for the $D_{1}$ and $D_{2}$. Lots $D_{3}$ and $D_{4}$ have the lowest values. For Chlorophyll (b) there were no large differences between the D1, D2 and control plants, while the lowest values were D3 and D4 with 0.45 and $0.3 \mu \mathrm{g} / \mathrm{g}$ FM The first and 0.52 and 0.46 for the second treatment. On the other hand, the highest carotenoid contents are present in lot $\mathrm{D}_{2}$, whereas $\mathrm{D}_{4}$ has the lowest contents. After a second application of the treatment, all the activity of the chlorophylls was lowered, the activity of the carotenoid pigments is greater compared to the chlorophyll.

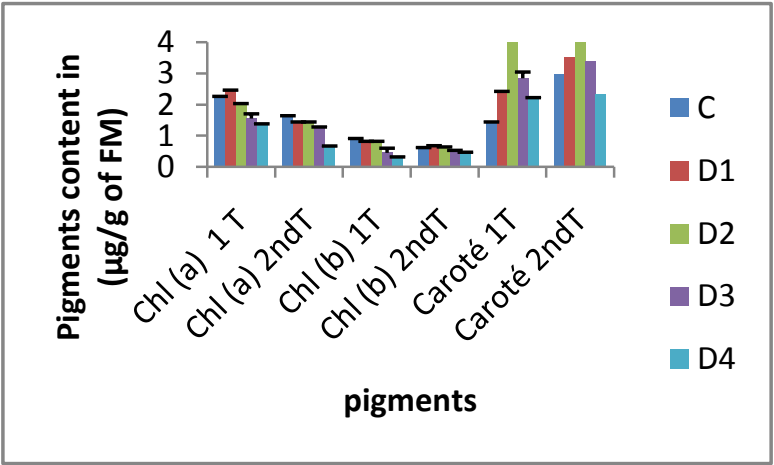

Fig. 3.Effect of Hexaconazoleon pigment content chlorophylls and carotenoids of green bean streated with different concentrations: $D_{1}(0.4 \mathrm{ml} / \mathrm{l}), D_{2}(0.8 \mathrm{ml} / \mathrm{l})$, $D_{3}(1.2 \mathrm{ml} / \mathrm{l}), D_{4}(1.6 \mathrm{ml} / \mathrm{l})$, conducted in two processing operations at the $6^{\text {th }}$ and $9^{\text {th }}$ week.

\section{b. Total protein content}

ANOVA.1 shows the existence of very highly significant differences in protein content (Tab.2). In fact, the contents of the leaves treated with dose $\mathrm{D}_{3}$ are the highest value $5.36 \mu \mathrm{g} / \mathrm{mg}$ of MF followed by $\mathrm{D}_{2}$ with $4.4 \mu \mathrm{g} / \mathrm{mg}$ of FM. Conversely, $\mathrm{D}_{4}$ recorded the lowest value $(3.5 \mu \mathrm{g} / \mathrm{mg} \mathrm{FM})$ for the first treatment and $3.1 \mu \mathrm{g} / \mathrm{mg}$ FM for the second treatment.

\section{c. Total sugar content}

The results concerning the effect of Hexaconazole on the sugar content are shown in Figure 5. Indeed, the results obtained show that this characteristic varies in a very highly significant way (Table 2).

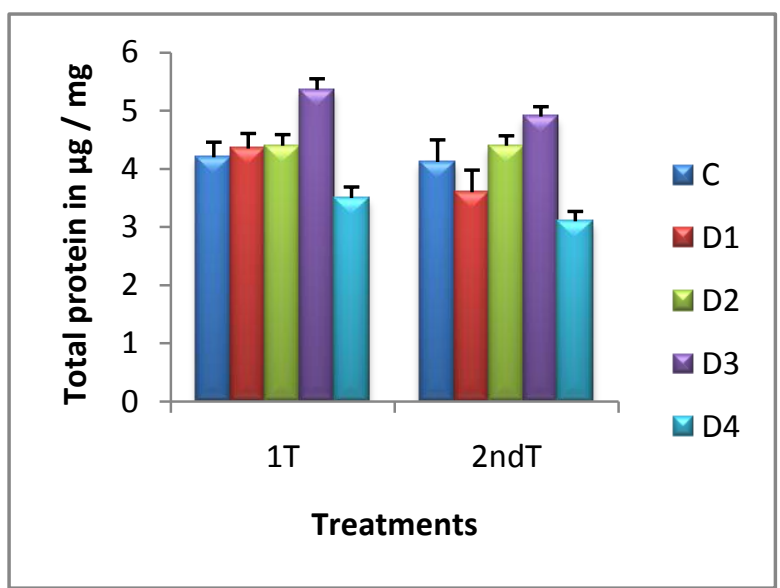

Fig. 4. Effect of Hexaconazoleon total proteins content of green beans treated with different concentrations: D1 $(0.4 \mathrm{ml}$ /l), $D_{2}(0.8 m l / l), D_{3}(1.2 m l / l), D_{4}(1.6 m l / l)$, conducted in two processing operations at the $6^{\text {th }}$ and $9^{\text {th }}$ week.

It is noted that the most important content of sugars was found in the plants treated with the lowest dose (D1) which seems to favor the synthesis of the carbohydrates with a value of $10.64 \mu \mathrm{g} / \mathrm{mg}$ of FM. The doses $D_{3}$ and $D_{4}$ cause an inhibition of the synthesis of these compounds since the lowest values are 0.51 and 0.4 for the first treatment and0.31, 0.22 $\mu \mathrm{g} / \mathrm{mg}$ for the second treatment.

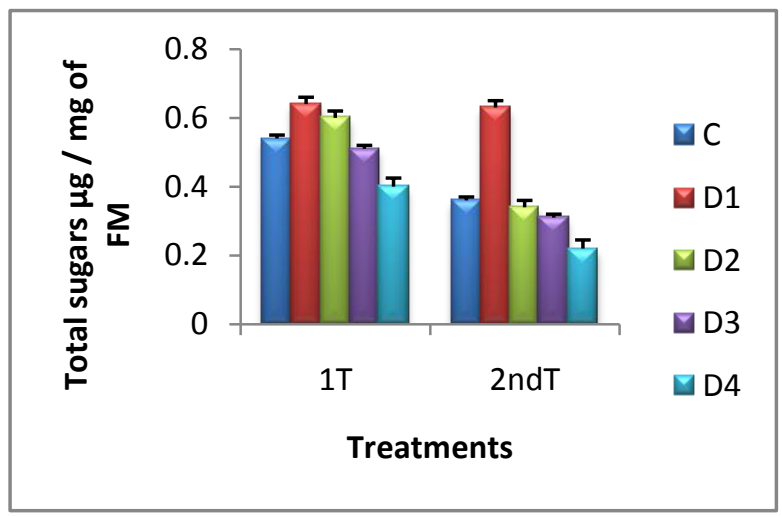

Fig. 5. Effect of Hexaconazoleon total sugar content of green beans treated with different concentrations: $D_{I}(0.4 \mathrm{ml} /$ l), $D_{2}(0.8 \mathrm{ml} / \mathrm{l}), D_{3}(1.2 \mathrm{ml} / \mathrm{l}), \mathrm{D}_{4}(1.6 \mathrm{ml} / \mathrm{l})$, conducted in two processing operations at the $6^{\text {th }}$ and $9^{\text {th }}$ week.

Table 2. Observed value F observed (Fobs) Analysis of variance ANOVA 1 for the biochemical parameters of two treatments.

\begin{tabular}{|c|c|c|c|c|c|c|}
\hline $\begin{array}{l}\text { Source of } \\
\text { variation }\end{array}$ & d.f & Chl(a) & Chl(b) & Carot & $\begin{array}{c}\text { Total } \\
\text { proteins }\end{array}$ & $\begin{array}{c}\text { Total } \\
\text { sugars }\end{array}$ \\
\hline \multicolumn{2}{|c|}{ Treatments } & $\begin{array}{ll}\mathrm{T}_{1} & \mathrm{~T}_{2}\end{array}$ & $\begin{array}{ll}T_{1} & T_{2} \\
\end{array}$ & $\begin{array}{ll}\mathrm{T}_{1} & \mathrm{~T}_{2} \\
\end{array}$ & $\begin{array}{l}\mathrm{T}_{1} \mathrm{~T}_{2} \\
\end{array}$ & $\mathrm{~T}_{1} \mathrm{~T}_{2}$ \\
\hline $\begin{array}{l}\text { Conc } \\
\text { Error }\end{array}$ & $\begin{array}{c}4 \\
25\end{array}$ & $130^{\mathrm{a}} 713,3^{\mathrm{a}}$ & $180^{\mathrm{a}} 53,3^{\mathrm{a}}$ & $111,3^{\mathrm{a}} 87,1^{\mathrm{a}}$ & $6.3^{\mathrm{a}} 8.1^{\mathrm{a}}$ & $\begin{array}{c}25^{\mathrm{a}} \\
140.6^{\mathrm{a}}\end{array}$ \\
\hline Total & 29 & & & & & \\
\hline
\end{tabular}

Abreaction:

d.f: degree of freedom; Ch.: Chlorophyll; Carot: Carotenoids; POD: peroxidase; CAT: catalase; GST:glutathione-sulfo-transferase; GSH: Glutathione a) P $<0.05$ : significant differences; b) $\mathrm{P}<0.01$ : Highly significant 
differences; c) $\mathrm{P}<0.001$ : very highly significant differences; ns: not significant; $\mathrm{T}_{1}: 1^{\text {st }}$ treatment, $\mathrm{T}_{2}: 2^{\text {nd }}$ treatment.

\section{Yield Components}

\section{a. Number Of Flower Knotted}

Figure 6 shows knotted flower decay each time the dose increases. The highest number is that of the control with 18 pods, the lowest values are those of D3 and D4 with 13 and 10 pods respectively, the number of knotted flowers of treated plants having received two treatments is lower compared to plants which received only one treatment. The analysis of the variance proves the existence of very highly significant differences (Table 3 ).

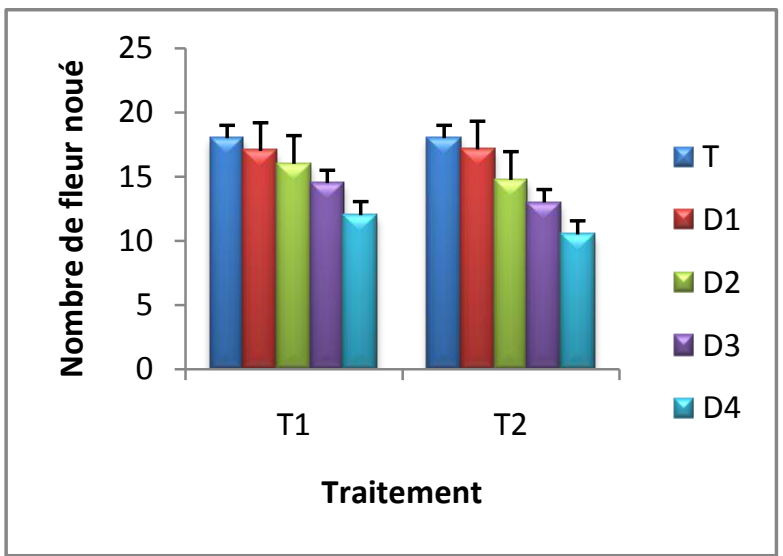

Fig. 6.Effect of Hexaconazole on the number of knotted flower of green beans treated at different concentrations: $D_{1}$ $(0.4 \mathrm{ml} / \mathrm{l}), D_{2}(0.8 \mathrm{ml} / \mathrm{l}), D_{3}(1.2 \mathrm{ml} / \mathrm{L}), D_{4}(1.6 \mathrm{ml} / \mathrm{l}) \mathrm{At}$ the $6^{\text {th }}$ and $9^{\text {th }}$ week.

\section{b. Number of pods / plants}

Figure 7 shows once again the effect of the fungicide on the number of pods. The analysis of the variance to a classification criterion shows that this characteristic varies in a very highly significant way (Tab.3) since ( $P$ $<0.001)$. The control plants recorded the highest averages 23.5 and the plants treated with D3 and D4 were characterized by the lowest values 15.75 and 11.4 pods respectively.

\section{c. Weight of 100 seeds}

Figure 8 illustrates the weight averages of 100 seeds after application of treatments with different doses plus control, analysis of the one-criterion variance shows that there is a very highly significant difference between the mean $(\mathrm{P}<0.001)$ (Tab.3), for the second treatment a high value of D1 was recorded with $110 \mathrm{~g}$, D2 with 80.6, D3 and D4 last with 34.3 and $21.3 \mathrm{~g}$.

\section{DISCUSION}

The results obtained are validated by a statistical study, the analysis of the variance with a single classification criterion according to Dagnelie [20].

The results obtained from this work show that the length of the plants during the vegetative cycle seems to have a difference between the various treatments, especially after the second application, the leaf area are influenced by the fungicide. It is observed that the doses used D3 and D4 cause a regression of the agronomic parameters, with a cumulative effect after the second application (Fig 1. 2, Table 1). These results seem to corroborate those obtained by authors $[21][22][23]$ the recorded agronomic parameters of regressions by treatments with triazoles [24][25].

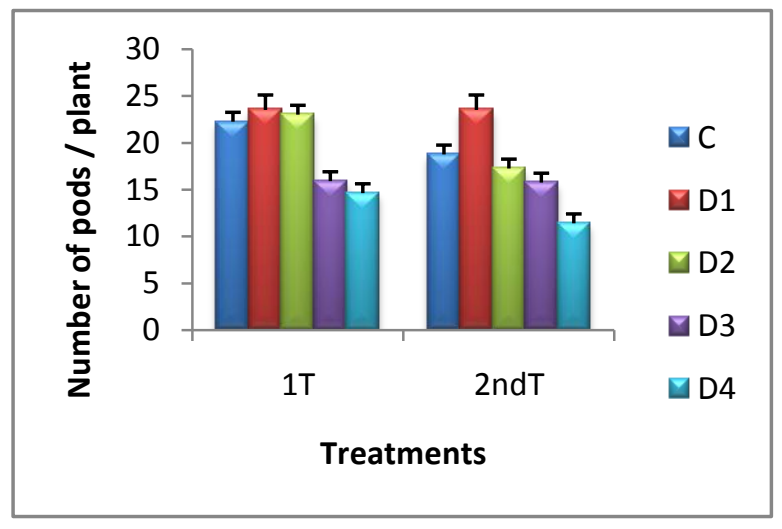

Fig. 7.Hexaconazole the effect on the number of pod / plant green beans treated at different concentrations: $D_{l}$ $(0.4 \mathrm{ml} / \mathrm{l}), D_{2}(0.8 \mathrm{ml} / \mathrm{l}), D_{3}(1.2 \mathrm{~mL} / \mathrm{L}), D_{4}(1.6 \mathrm{ml} / \mathrm{l}) \mathrm{At}$ the $6^{\text {th }}$ and $9^{\text {th }}$ week.

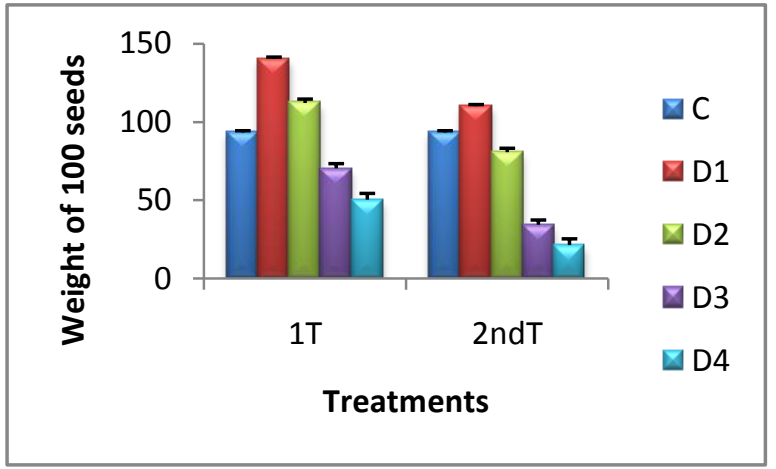

Fig. 8. Hexaconazole effect on Weight of 100 seeds of green beans treated at different concentrations: $D_{1}(0.4 \mathrm{ml} /$ l), $D_{2}(0.8 \mathrm{ml} / \mathrm{l}), D_{3}(1.2 \mathrm{~mL} / \mathrm{L}), D_{4}(1.6 \mathrm{ml} / \mathrm{l})$ at the $6^{\text {th }}$ and $9^{\text {th }}$ week.

Photoreceptor pigments (chlorophylls and carotenoids) play an important role in the capture of light energy and its transformation into potential chemical energy for the reduction of atmospheric $\mathrm{CO}^{2}$ into organic molecules such as carbohydrates and proteins. Under the influence of the fungicide, the synthesis of these pigments was decreased.

Drastically in plants treated with high doses and the effect of the fungicide is cumulative after application of the second treatment. These results are in perfect agreement with those found by authors [26][27]. Pigment reduction is important using the highest doses of the fungicide [28], this decrease in pigments results 
in a reduction in net photosynthesis [29]. It affects the thylakoidal membrane of photosystem1 [30]. And modifies the phytosterol profile and thylakoidal functions [31][32]. Cucumber plants treated with atriazole fungicide showed the same finding. [33] While Dose 1, which is considered the recommended half-dose of the fungicide, appears to favour the synthesis of chlorophyll (a) and Carotenoids. Similar results have been found by [34]. This can be explained by the fact that Hexaconazole is an active member of the triazole family with properties involved in the regulation of plant growth [35] and inhibits peroxidation Lipids [36][37]. Concerning the total sugars it was noted that the lower doses D1 and $\mathrm{D}_{2}$ induced more synthesis compared to the controls of the sugars. This leads us to say that the low-dose fungicide can cause a respiratory exaltation by slightly activating the cellular metabolism Which will become, as it were, "a source of energy and carbon" for plants [38][39]. On the other hand, the application of high doses leads to a fall in metabolic activities, which generally results in a decrease in photosynthesis, for proteins their contents increase with the dose applied, the more the dose increases the more the content increases [40][41].

The yield components such as knotted flower number during the vegetative cycle appear to have a difference between the various treatments. It is observed that the doses used $\mathrm{D}_{3}$ and $\mathrm{D}_{4}$ cause a regression of knotted flower number with a cumulative effect at the second application. These results appear to be similar to those obtained by Lakshmanan in 2007 [42], which explain that a certain amount of fungicide can be influenced by agronomic parameters.

The number of pods and the weight of 100 seeds of plants treated with Dose 1 resulted in some advantage over the Control and $\mathrm{D}_{2}$. Plants use the fungicide as a low-dose source of energy and carbon [43], Knowing that Hexaconazole is an active member of the triazole family and has properties in the regulation of plant growth [44].

\section{Conclusion}

As a general conclusion, we can say that this study of the action of the fungicide Hexaconazole on the green bean variety Djedida, allowed us to know that the high concentrations in relation to the ideal concentration, recommended by the laboratory supplier product had a negative impact on agronomic parameters made (elongation of plants, leaf area)throughout the test with the higher doses.

Furthermore, with regard to photoreceptor pigments, chlorophylls, carotenoids and sugars, aslight stimulation of the synthesis of these pigments was found by the low doses applied as compared to the controls. For total proteins, on the other hand, it was noted that only high doses resulted in a high accumulation of these proteins.

For yield components, knotted flower number, number of pods / plant and weight of 100 seeds show that plants are influenced by high doses of fungicide D3 (1.2ml / 1) and D4 (1.6 ml / 1) and revealed differences between highly and very highly significant with a cumulative effect after a second application of treatment, plants treated with low doses D1 and D2 did not appear to be influenced by treatment.

To conclude, it can be said that the use of the fungicide may be beneficial for yield improvement, plant resistance to diseases and the quality of crops harvested, but only on one condition: use of the dose Ideal otherwise it would generate oxidative stress and a depressive effect on irreversible plants.

\section{REFERENCES}

[1] Bouziani M., (2007). The excessive useof pesticides.Serious healthconsequences. The guide of medicine and health. HealthMaghreb, p 75.

[2] Boutaleb J. A., (1992). Population Dynamics of Myzuspersicae (Sulzer) (Homoptera: Aphididae) to Douiet(greenhouse) and highlightingof strains resistant toinsecticides by colorimetric and toxicologicaltests. Thesis, National School of Agriculture. Meknes, 135p.

[3] Sekkat A. and Boutaleb J. A., (1993). Highlighting oftheresistance of Myzus persicae (Sulzer) on peachandpepper in Morocco. International Conference on Pestsin Agriculture, Montpellier, France. Vol II/III: 873-880.

[4] Boutaleb J. A. and Targui S., (2003). Classification of pesticides used inappleorchardin the Meknes regionbased ontheir specific effectson the health of the consumer and the environment. Environmental Geosciences. 15-16 JuneIbn Tofail University, Kenitra Morocco.

[5] Senesi N., (1993). Organic pollutant migration in soils as affected by soil organic matter: Molecular and mechanistic aspects. A atoasi series, 32: 47-74.

[6] W.F. Müller, I. Scheunert, K. Rozman, W. Kögel, D. Freitag, E. Richter, F. Coulston, F. Korte, (1978). Comparative metabolism of hexachlorobenzene and pentachloronitrobenzene in plants, rats, and rhesus monkeys, Ecotoxicology and Environmental Safety, 2(3), Pages 437-445, ISSN 0147-6513, http://dx.doi.org/10.1016/S0147-6513(78)80017-7.

(http://www.sciencedirect.com/science/article/pii/S0147 651378800177)

[7] Bollag J.M., (1982). Microbial metabolism of pesticides in Rosazza. JP (ed). Microbial transformation of bioactive compound. CRC. Press. Inc. Bocca Rton.,1: 10-15.

[8] Bonnemain, J.L. et Chollet F., (2003). Phytosanitaryarsenal against the enemies of plants.General considerations. Academy of Sciences. Scientific and medicalpublications, Elsevier SAS.

[9] Liu D., Zou J., Meng Q., Zou J., Jiang W., (2009) Uptake and accumulation and oxidative stress in garlic ( Allium sativum L.) under lead phytotoxicity. Ecotoxicology, 18: 134-43. 
[10] Pandey S., Gupta K., and Mukherjee A.K.,(2007). Impact of cadmium and lead on Catharanthus roseus: a phytoremediation study. J. Environ. Biol., 28:655-62.

[11] Xiao W., Hao H., Liu X.Q., Liang C., Chao L., Su M.Y., Hong F.H.,(2008).Oxidative stress induced by lead in chloroplast of Spanish. Biol. Trace. Elem. Res., 126: 257-68.

[12] Verma S., Dubey R.S., (2003). Lead toxicity induces lipid peroxidation and alters the activities of antioxidant enzymes in growing rice plants. Plant. Sci., 164:645655.

[13] Sharma P., Dubey R.S., (2005). Lead toxicity in plants. Braz. J. Plant Physiol., 17: 35-52.

[14] Berova, L., (2002). Effect of Paclobutrozole on wheat seedlings under low temperature stress. Bulg. J. Plant phyala, 28 (100)1-2, pp: 75- 84.

[15] Paul M.H., Planchon C. et Ecochard R., (1979). Study of the relationshipbetweenleaf developments. The development cycle on productivityatSoya. Ann.Amel.pl, 2955, 479-492.

[16] Holden, M., (1975)- Chlorophylls I, chemistry and biochemistry of plant pigments. $2^{d}$ Edition. T. W. Goodwin. Academic Press Edition., New York, pp: 1-37.

[17] Arnon, 1949. in Alpert, P. 1984. Analysis of Chlorophyll Content in Mosses through Extraction in DMSO.The Bryologist, 87(4): 363-365.

[18] Bradford, M ., 1976 - A rapid and sensitive method for the quantitation of microgram quantities of protein utilising the principale of protein -dye binding Analytical Biochimistry ., 72: 248-254.

[19] Shields, R., et Burnett, W., 1960-Determination of protein bound carbohydrate in serum by a modified anthrone method. Anal.Chem. 32. pp. 885-886.

[20] Dagnelie, P., (1999). Theory andstatistical methodsVol, 2, 110-152.

[21] SmileyR.W., Patterson L .M., Rhinhart E.L., (1996). Fungicide seed treatment effects on emergence of deeply planted winter wheat. Columbia Basin Agricultural Research. Annual Report. Spec. Rpt.961, 85-96

[22] SiddiquiZ.S., Ahmed S., Zaman A., (2000). Effects of Methyl Thiophenate on Germination, Seedling Growth, Biomass and Phenolic Content of Resistant and Susceptible Varieties of Triticum aestivum L. Journal of Biological Sciences, 4(10).

[23] Jaleel C A., Gopi R., Panneerselvam R., (2007). Alterations in lipid peroxidation, electrolyte leakage, and proline metabolism in Catharanthus roseus under treatment with triadimefon, a systemic fungicide, $C . R$. Biol, 330, 905-912.

[24] Jaleel C.A., Gopi R., Panneerselvam R., Manivannan P., Sankar B., Panneerselvam R., (2008). Interactive effects of Triadimefon and salt stress on antioxidative status and ajmalicine accumulation in Catharanthus roseus. Acta. Physiol. Plantarum,doi: 10.1007/s11738-007-0119-1.

[25] Binet, P., (1989). Metabolism andadaptationof higher plants to water, thermal and saline stress. ux. Bull. Ecol.,T 20 (1), 41- 49.
[26] Berova, L., (2002). Effect of paclobutrozole on wheat seedlings under low temperature stress. Bulg. J. Plant phyala. 28(1001-2). $75-84$.

[27] Youbi M., (2005). Effects of two fungicides Arterea and Punch newly introduced in Algeria on the physiology and respiratory metabolismDurum wheat (Triticum durum.Desf.) ;Université Badji Mokhtar Annabap 75

[28] Tort, N., Turk Yilmaz, B., (2003). Physiological effects of captan fungicide on pepper (Capsicum annum L.). Pakistan Journal of Biological Sciences, 6 (24), 20262029.

[29] Xia XJ, Huang YY, Wang L, Huang LF, Yu YL, Zhou YH, Yu JQ., (2006). Pesticides- induced depression of photosynthesis was alleviated by 24- epi brassinolide pretreatment in Cucumis sativus L. Pestic Biochem Physiol, 86, 42-48

[30] Yoon, J.Y., Shin, J.S., Shin, D.Y., Hyun, K.H., Burgos, N. R., Sungbeom, L., (2011). Tolerance to paraquatmediated oxidative and environmental stresses in squash (Cucurbita sp) Leaves of various ages. PesticideBiochemistry and Physiology, 99, 65-76

[31] Benton J.M, Cobb A.H (1997).The modification of phytosterol profiles and in vitro photosynthetic electron transport of Galium aparine L. (cleavers) treated with the fungicide, Epoxiconazole. Plant Growth Regul, 22: 93-100

[32] Petit A.N., Wojnarowiez G., Panon M.L., Baillieul F., Clément C., Fontaine F. et Vaillant-Gaveau N., (2008). Botryticides affect grapevine leaf photosynthesis without inducing defense mechanisms.,P 79-92.

[33] Van Iersel MW, Bugbee, (1996). Phytotoxic effects of Benzimidazole fungicides on breeding plants. J Am Soc. Hortic. Sci, 121, 1095-1102

[34] Hojati M., Modarres-Sanavy S.A.M., Ghanati F., Panahi M., (2010). Hexaconazole induces antioxidant protection and apigenin-7-glucoside accumulation in Matricaria chamomilla plantssubjected to drought stress. P 97.

[35] Fletcher R. A., Gill A., Davis T.D., Sankhla N., (2000). Triazoles as plant growth regulators and stress protectants. Hort. Rev, 24: 55-138.

[36] Talat Parweena., Sumira Janb., Mahmood Uzzafarb., Tasneem Fatmaa., Zahid Hameed., Siddiqui Sep., (2014). Selective effect of pesticides on plants. Taylor \& Francis Reviews, 15, 21-23

[37] Bourouhou.M, Slimani. S, Abdelmadjid.S, Boudelaa.M, Ladjama. A., (2015). The effect Hexaconazole on Agronomic, Physiological and enzymatic parameters in bean Phaseolus vulgaris cv. Djedida, Advances in Environmental Biology, 9(22), 118-128.

[38] May, M.J. and Leaver, C.J., (1993). Oxidative stimulation of glutathione synthesis in Aradopsis thaliana suspension culture. Plant Physiology, 103. 621627.

[39] Viskari, E.L., Surakka, J., Pasanen, P., Mirma, A., Kossi, S., Ruuskanen, J., and Holopainen, J.R., (2000). Response of spruce seeding (Picea abies) to exhaust gas 
under laboratory conditions. Plant- insect interactions Environmental Pollution, 107. 89-98.

[40] Briat, J.F., Lebrun, M., (1999). Plant responses to metal toxicity. Plant Biology and Pathology, 322, 43-54.

[41] Bert, V., (2000). Tolérance aux métaux lourds et accumulation chez Arabidopsis halleri (Brassicaceae). Thèse .Université des Sciences et Technologies de Lille, UFR de Biologie.

[42] Lakshmanan G.M.A., Cheruth Abdul Jaleel, Gomathinayagam M., Panneerselvam R., (2007). Changes in antioxidant potential and sink-organ dry matter with pigment accumulation induced by Hexaconazole in Plectranthus forskholii. .Briq, 814-820.

[43] Jaleel C A. Gopi R., Panneerselvam R., Manivannan P., (2007). Antioxidative potentials as a protective mechanism in Catharanthus roseus (L.) G. Don. Plants under salinity stress, Turk. J. Bot., 31, 245-251.

[44] Hassanpour H, Khavari-Nejad R A, Niknam V, Najafi F, Razavi K, (2013). Penconazole induced changes in photosynthesis, ion acquisition and protein profile of Mentha pulegium L. under drought stress, Physiol Mol Biol Plants19(4),489-498.

\section{Authors Details:}

\section{Bourouhou Mourad}

Faculty. of Science, Laboratory Plant Biology and

Environment. Badji Mokhtar University, Annaba,

Algeria

email: mour.bourouh@hotmail.com

\section{Badouna Baha-Eddine*}

Institute Agro-Veterinary, Taoura. Laboratory Live

Science and Technology. University Mohamed

Chérif Messaadia, Souk-Ahras, Algeria.

email: badounabaha@gmail.com

Boudelaa Mokhtar

Faculty. of Science, Laboratory Plant Biology and

Environment. Badji Mokhtar University, Annaba,

Algeria

email: m.boudel@gmail.com

Edidtor-in-Chief: Sahadev Roy 